\title{
The Impact of Brand Image and Service Quality on Consumer Loyalty in the Banking Sector
}

\author{
Submitted 21/05/19, $1^{\text {st }}$ revision 13/08/19, $2^{\text {nd }}$ revision $20 / 10 / 19$ accepted $24 / 11 / 19$
}

\author{
Sri Wahyuni ${ }^{1}$, Imam Ghozali ${ }^{2}$
}

\begin{abstract}
:
Purpose: The study aims to analyze the extent in which a bank is trying to provide the best service to survive in the long term and what is demanded from it to be the best banking company, by examining the increase of loyalty and Words of Mouth (WOM) of customers through brand image, service quality and customers satisfaction.

Design/methodology/approach: This study is based on the answers of 130 respondents from the PT. Bank Rakyat Indonesia. The used method to colect data is the distribution of a questionnaire using a scale from 1-10. For the data analysis was used the Structural Equation Modeling with AMOS version 21 to test the causality of 8 research hypotheses.

Findings: The results of this study indicate that there is a positive effect between the quality of service and customer satisfaction, loyalty and WOM, while the brand image has no effect on satisfaction, loyalty and WOM. The result of this research shows that the indirect effect of service quality variable on loyalty is better than that of WOM.

Practical implications: The findings suggested that the Bank BRI marketers should be more persistent in publically communicating the bank's products which are offered to customers and prospective customers.

Originality/value: This study examined the effect of brand image, service, customer service in order to increase customer satisfaction, loyalty, and WOM at the largest bank in Indonesia.
\end{abstract}

Keywords: Loyalty, brand image, quality service, satisfaction.

JEL code: $M 31$.

Paper type: Research article.

\footnotetext{
${ }^{I}$ Faculty of Economics and Business, Diponegoro University Semarang, and ABFII Perbanas, Jakarta Indonesia, email: sri.wahyuni@ perbanas.id

${ }^{2}$ Faculty of Economics and Business, Diponegoro University, Semarang, Indonesia, email: imam.ghozali@live.undip.ac.id
} 


\section{Introduction}

The increasingly modern technology, wide knowledge level, and the comunity's need for banking services is highly contributing to a constant increasing number of transactions and heavy banking activity. The banking business is a service business that is based on trust, so that the service quality becomes a very important factor in determining the success of this business (Sudarti and Putri, 2013). In terms of marketing, the consumer awareness regarding the company's products is highly dependent on the brand image and services offered, resulting in consumer satisfaction, loyalty and their will to further recommend the product. In theoretical basis, some studies have highlighted that the brand image and customer satisfaction Kurniawati et al. (2014), Lasander (2013), have a significant effect on customer satisfaction, while other studies from Sondakh (2014) stated that the effect is insignificant. Regarding the relationship between services and satisfaction, Endarwita (2013), Huda and Wahyuni (2012) indicated that these have a significant effect on satisfaction, while Wahyuni and Safaria (2014) showed the contrary.

Ersi and Semuel (2014), Jain and Kumar (2015) indicated that satisfaction has a significant effect on loyalty, while Endarwita (2013), Huda and Wahyuni (2012) stated the opposite. Harahap et al. (2014) stated that the brand image has a positive effect on loyalty, while Kurniawati et al. (2014), Suwandi et al. (2015) stated that its effect is not significant. Ismail (2014), Jain and Kumar (2015) indicated that the service's quality significantly affects loyalty, while Harahap et al. (2014), Huda and Wahyuni (2012) revealed that its effect on loyalty is not significant. Based on these research gaps, the purpose of this study is to analyse and find empirical evidence of the effect of brand image in increasing the customer's satisfaction, the effect of service on customer satisfaction, of customer satisfaction on loyalty, of brand image on customer loyalty and of service quality on customer loyalty at the PT. Bank Rakyat Indonesia.

\section{Literature Review and Hypotheses}

\subsection{Brand Image, Satisfaction, Loyalty, and Words of Mouth (WOM)}

Brand image can provide added value both to companies and customers. The added value created from brand image, can be, among others, in form of increased customer satisfaction. The brand image of a company can affect the customer's satisfaction. As the image of a brand in the sight of customers is getting better and more positive, the likelihood customers being satisfied with the brand is getting higher. Previous researches regarding the effect of brand image on satisfaction conducted by Kurniawati et al. (2014), Lasander (2013), Suwandi et al. (2015) indicated that the brand image has significant effect on consumer satisfaction.

H1: Brand image has a positive and significant effect on customer satisfaction. 
To build and maintain the customer's confidence in their brand, banks must properly and correctly manage their brand image. As the brand image is an indicator of the customer's loyalty towards a brand, the image owned by a brand can affect the formation of customer loyalty towards it. Previous research on the effect of brand image on loyalty conducted by Harahap et al. (2014) indicated that the brand image has positive effects on loyalty.

\section{H2: Brand image has a significant and positive effect on customer loyalty.}

Words-of-mouth communication is a personal conversation and an informal exchange of information in community groups, that affects not only the consumer choices and purchasing decisions, but also shapes the consumer's expectations, preuse attitudes (Herr et al., 1991), and even post-use perceptions of products or services. Some WOM studies reported a great impact of print advertising, personal selling, and radio advertising, indicating that some of these effects may occur.

\section{H3: Brand image has a significant and positive effect on Words of Mouth (WOM).}

\subsection{Service Quality, Satisfaction, Loyalty and Words of Mouth (WOM)}

The brand image can provide added value both to companies and customers. Added value created from brand image, can be, among others, in form of increased customer satisfaction. The brand image of a company can affect the level of satisfaction felt by the customers. A better and more positive image of a brand in the eyes of customers appears when customers are more satisfied with a brand. Previous researches regarding the effect of brand image on satisfaction conducted by Kurniawati et al. (2014), Lasander (2013), Suwandi et al. (2015) indicated that brand image has a significant effect on customer satisfaction.

\section{H4: Service quality has a significant and positive effect on customer satisfaction.}

The quality of services in the banking sector has a positive impact on customer loyalty level because the higher the quality of services provided by banks, the higher the level of customer loyalty. Previous researches on the impact of service quality on customer loyalty conducted by Ismail (2014), Jain and Kumar (2015), Sudarti and Putri (2013), Suwandi et al. (2015), Wahyuni and Pranoto (2013) showed that the quality of service has a significant effect on loyalty.

H5: Service quality has a significant and positive effect on customer loyalty.

Words-of-mouth (WOM) has been recognized as one of the most influential sources of information. The advancement of information technology and the emergence of online social networking sites have changed the way information is transmitted. This phenomenon affects consumers because accessible information can greatly influence the consumption decisions. Jalilvand and Samiei (2012) research found that e-WOM 
is one of the most effective factors influencing the brand image and the consumers' buying intentions in the market.

H6: Service quality has a significant and positive effect on Words of Mouth (WOM).

\subsection{Customer Satisfaction, Loyalty and Words of Mouth (WOM)}

Customers' satisfaction is very important for service providers, because it represents one of the keys to success for business. Customers must be satisfied, because the satisfaction felt by the customers would make them loyal. It means that customers' loyalty is formed and influenced by a sense of satisfaction felt by customers. Ersi and Semuel (2014), Jain and Kumar (2015), Sudarti and Putri (2013), Sondakh (2014), Wahyuni and Pranoto (2013) indicated that the satisfaction variable has a significant effect on loyalty.

H7: Customer satisfaction has a positive and significant effect on customer loyalty.

WOM focuses on the reasons why consumers are proactively spreading the words about products and services that they used and received. Some of these studies have reported factors that result from extreme satisfaction or dissatisfaction (Maxham and Netemeyer, 2002; Richins, 1983), commitment to companies, long-term relationships with companies (Wangenheim and Bayon, 2004), and product novelty that encourage such consumer behavior.

H8: Satisfaction has a significant and positive effect on Words of Mouth (WOM).

\section{Research Methodology}

The type of this research is quantitative, data was obtained by measuring the value of one or more variables in the samples. The measurement of brand image was done by using 4 indicators namely brand awareness, perceived quality, brand associations and brand loyalty. Customer satisfaction by Kotler and Keller (2007) is measured by using 3 indicators, namely experience, expectation and overall satisfaction. Service quality according to Kotler and Armstrong (2010) is measured with 5 indicators namely tangible, reliability, responsiveness, assurance and empathy. Customer loyalty is measured with 4 indicators namely customer loyalty, recommendation to family and friends, attractiveness and brand association. WOM is measured using 3 indicators of eagerness to transact, eagerness to give information, always directing and encouraging.

For the data collection were used closed-ended and open-ended questions. With closed-ended questions the respondents were asked to provide an assessment with a score of one 1 (strongly disagree) to ten 10 (strongly agree). 
The samples used in this research are customers of Britama and Simpedes at PT. Bank Rakyat Indonesia, Tbk. The sampling technique used is nonprobability sampling with purposive sampling. The sampling is in accordance with the criteria that have been determined as follows: (1) customers using savings products Britama and Simpedes, (2) customers using savings products Britama and Simpedes within a period of one year or longer than one year, because customers for a period of one year or more than one year can be categorized as loyal customers. The sample size that must be met in this model is of a minimumof 100 and for each estimated parameter is done a comparison of 5 observations. Therefore if we develop a model with 20 parameters, then the minimum sample that must be used is of 100 (Ferdinand, 2014). The number of samples in this study is of 130 respondents.

The analysis instrument used in this research is Structural Equation Modeling (SEM) with Analysis of Moment Structure (AMOS) 21.0 program (Ghozali, 2013). Structural Equation Modeling produces equations that can be used to estimate the direct effect, the indirect effect and the effect of total variables on other variables in a study.

\section{Results}

\subsection{Full Model of Structural Equation}

The model in this study was executed based on 7 evaluations. The value of decreasing Chi-square shows that there is no difference between the tested models with saturated models, CMin / DF $\leq 2.00$, GFI (Goodness of Fit Index) and AGFI (Adjusted Goodness of Fit Index) $\geq 0.90$, TLI and CFI $\geq 0.95$, RMSEA (Rood Mean Square Error of Approximation $) \leq 0.08$. The calculation results show that the Chisquare value in this study is 392.77 with a probability of 0.06 ; CMIN / DF value is 1,616 , GFI $=0.928$, and $\mathrm{AGFI}=0.959$; TLI $=0.954$; CFI is 0. 960, RMSEA is 0.069 . Thus, the structural equation model developed is fitted quite well.

\subsection{Testing Variable Causality}

The testing for $\mathrm{H} 1$ states that there is a significant influence of brand image on satisfaction revealed in the CR value of 0.904 with a $\mathrm{p}$ value of 0.366 . It is proved that the brand image variable has a positive and insignificant effect on satisfaction. The testing shows the positive and significant effect of service quality on satisfaction with a CR value of 2.76 and $p$ value of 0.006 . This means that Bank BRI provides convenient facilities felt by customers, the BRI Bank employees have a good expertise and reliable knowledge about the products, the bank employees provide solutions when customers have difficulties about the products, the bank employees are consistent and polite in providing services in accordance with the customer expectations. Customers feel benefited from the savings products of Bank BRI and overall, customers are satisfied with the services provided by Bank BRI. 
Table 2. Variable Causality Test

\begin{tabular}{|l|l|l|l|l|l|l|}
\hline \multicolumn{2}{|l|}{ Hypotheses } & Estimate & S.E. & C.R. & P \\
\hline satisfaction & $<---$ & brand & .209 & .231 & .904 & .366 \\
\hline satisfaction & $<---$ & service & .530 & .192 & 2.764 & .006 \\
\hline loyalty & $<---$ & brand & -.327 & .169 & -1.931 & .053 \\
\hline loyalty & $<---$ & service & .325 & .141 & 2.305 & .021 \\
\hline loyalty & $<---$ & satisfaction & .217 & .090 & 2.412 & .016 \\
\hline wom & $<---$ & service & .298 & .162 & 1.842 & .065 \\
\hline wom & $<---$ & brand & -.197 & .155 & -1.269 & .204 \\
\hline wom & $<---$ & satisfaction & .013 & .075 & .171 & .864 \\
\hline
\end{tabular}

The influence test of brand image on loyalty shows a CR value of -1.931 and $p$ value of 0.053 meaning that the brand image has a negative impact on loyalty. The brand image that has been built by BRI does not impact the customers' loyalty, and does not recommend to prospective BRI's customers.

The testing shows the positive and significant effect of service quality on loyalty with a CR value of 2.305 and $p$ value of 0.021 . This means that Bank BRI employees' services creates a sense of loyalty in customers, so customers do not want to use other banks, and will not open savings account with other banks even though they provide higher interest rates and better prizes, and customers are even willing to promote and talk about the savings products of Bank BRI to other banks. The testing reveals the positive and significant influence of satisfaction on loyalty through a CR value of 2.412 and $\mathrm{p}$ value of 0.16 , which means that after feeling satisfied with the services provided by bank BRI, the customers are willing to save more money at the bank, and tell about the savings products to their family and friends. But the service quality and brand image variable have positive and significant effect on WOM at alpha (a) level of $10 \%$.

The results show the positive and significant influence of service quality on WOM with a CR value of 1.842 and $\mathrm{p}$ value of 0.065 . Marketer needs to maintain a positive WOM from customers and must be creative in order to be able to attract potential customers from service quality. The hypothesis testing for the influence of brand image on WOM revealed a CR value of -1.269 and $p$ value of 0.204 which reveal a negative impact on WOM. The brand image that has been built by the BRI bank has not had a positive impact on customers who want to save at the BRI. If the marketers are not sensitive to WOM, thay can lead to a decreasing number of customers saving at BRI.

The results for the influence of satisfaction on WOM show a CR value of 0.171 with $\mathrm{p}$ value 0.864 , meaning that satisfaction does not affect the WOM. The marketers need to constantly increase the innovation and to focus on rebranding so that customers are more interested in saving at the BRI. The overall results show that the service quality satifies the customers better, compared to the brand image, in line 
with the effect of brand image, service quality and satisfaction on loyalty. Meanwhile, among the variables of brand image, service quality and satisfaction on WOM, it is also the service quality contributing the most (Table 2).

Table 2. Standardized Direct and Indirect Effects

\begin{tabular}{|l|l|l|l|l|}
\hline Model & Variables & service & brand & satisfaction \\
\hline & Satisfaction & .460 & .134 & - \\
\hline Direct effect & WOM & .841 & -.412 & .042 \\
\hline & Loyalty & .566 & -.420 & .434 \\
\hline Indirect effect & Satisfaction & - & - & - \\
\hline & WOM & .019 & .006 & - \\
\hline & Loyalty & .200 & .058 & - \\
\hline
\end{tabular}

\section{Conclusion}

The results show that the brand image does not have a significant and positive effect on customers' satisfaction. Moreover, service quality has a significant and positive effect on customer's satisfaction and on customer's loyalty. The findings revealed that customer satisfaction has a significant and positive effect on customers' loyalty. The findings show that service quality has the dominant contribution to satisfaction, WOM and loyalty compared to brand image. It means that the services provided by Bank BRI's employees are in accordance with customers' expectations, which has an impact on loyalty and WOM. Thee brand image in this study has less value than the brand association. This shows the respondent's lack of information to differentiate the products of one bank from the products of another bank.

The findings suggested that Bank BRI marketers should be more persistent in communicating to the public the bank's products which are offered to customers and prospective customers. Moreover, the indicator with the lowest value on customer loyalty and WOM is an indicator of recommendation. To maximally increase customer's loyalty and WOM the bank should care abut the service system, adequate facility, fast service, friendly employees and readiness to always help customers in fulfilling requirements and expectations.

\section{References:}

Endarwita. 2013. Effect of Product Quality and Service Quality on Customer Satisfaction and Loyalty of Simpang Empat Branch BRI Savings. Economic Appreciation eJournal, (1)3.

Ersi, D.Y and Semuel, H. 2014. CRM Analysis, Customer Satisfaction and Product Loyalty of SMEs Based on Flour Raw Materials in East Java. Marketing Management Journal, 8(1).

Ferdinand, A. 2014. Structural Equation Modeling. Fifth Edition. Semarang: UNDIP

Publishing Agency. 
Ghozali, I. 2013. Structural Equation Model. Concepts and Applications with the AMOS 21.0 Program, UNDIP Publishing Agency, Semarang.

Herr, P.M., Kardes, F.R. and Kim, J. 1991. Effects of word-of-mouth and product-attribute information on persuasion: An accessibility-diagnosticity perspective. Journal of consumer research, 17(4), 454-462.

Huda, A.N. and Wahyuni, S. 2012. Analysis of the Effect of Quality of Internet Banking Services and Level of Satisfaction on Customer Loyalty at PT Bank Rakyat Indonesia (Persero) Tbk Jakarta Social Security Branch Office. Business and Management Review, 2(2).

Ismail, R. 2014. Effect of Service Quality, Product Quality and Customer Satisfaction as Predictors in Increasing Customer Loyalty. Organization and Management Journal, 10(2).

Jain, P. and Kumar, A. 2015. Investigating the Moderating Role of Swithching Cost in the Relationship of E-Service Quality, Perceived Customer Value, Satisfaction and Loyalty towards Online Travel Agencies. International Journal in Management and Social Science, 3(3).

Kotler, P. and Keller, K.L. 2007. Marketing Management, Ed12. Volume 2. PT Indek Publisher.

Kotler, P. and Armstrong, G. 2010. Principles of Marketing: Competing Strategies to Build Lasting Customer Relations. Jakarta: Erlangga.

Kurniawati, D., Suharyono, and Kusumawati, A. 2014. Effect of Brand Image and Product Quality on Customer Satisfaction and Loyalty (Study of KFC Malang Branch KFC Customers). Business Administration Journal, 14(2).

Lasander, C. 2013. Brand Image, Product Quality and Promotion of its Effect on Consumer Satisfaction in Traditional Food (Survey of Household Industry of Nutmeg Audia Meat Dodol in Tahuna, Sangihe Regency). EMBA Journal, 1(3).

Maxham, J.G. and Netemeyer, R.G. 2002. Modeling customer perceptions of complaint handling over time: The effects of perceived justice on satisfaction and intent. Journal of retailing, 78(4), 239-252.

Jalilvand, R.M. and Samiei, N. 2012. The effect of electronic word of mouth on brand image and purchase intention: An empirical study in the automobile industry in Iran. Marketing Intelligence and Planning, 30(4), 460-476.

Richins, M.L. 1983. Negative word-of-mouth by dissatisfied consumers: A pilot study. The journal of marketing, 68-78.

Sondakh, C. 2014. Service Quality, Brand Image and its Impact on Customer Satisfaction and Customer Loyalty Savings (Study on BNI Taplus Manado branch customers). Business Research and Management Journal, 3(1).

Sudarti, K. and Putri, F.A. 2013. Increasing Customer Loyalty through Brand Reputation, Customer Satisfaction and Service Quality to Achieve Competitive Advantages. Media Economics and Management, 27(1).

Suwandi, Sularso, A. and Suroso, I. 2015. Effect of Service Quality, Price and Brand Image on Express Post Customer Satisfaction and Loyalty at Post Office Bondowoso and Situbondo.

Wahyuni, S. and Pranoto. 2013. Customer Service and Orientation Against Loyalty with Satisfaction as an Intervening Variable for BCA Credit Card Users. Management and Business e-Journal, 1(1).

Wangenheim, F. and Bayon, T. 2004. Satisfaction, loyalty and word of mouth within the customer base of a utility provider: Differences between stayers, switchers and referral switchers. Journal of Consumer Behavior, 3(3), 211-220. 